EUROPA REGIONUM TOM XXIII ROK 2015

DOI: $10.18276 /$ er.2015.23-18

\author{
GABRIELA RUTKOWSKA, PIOTR WICHOWSKI, \\ MAREK SROK \\ Szkoła Główna Gospodarstwa Wiejskiego w Warszawie
}

\title{
Analiza możliwości wykorzystania pomp ciepła dla budynku mieszkalnego zlokalizowanego w Euroregionie Beskidy
}

\section{Wprowadzenie}

0 becnie światowa energetyka poszukuje alternatywnych źródeł energii odnawialnych. Obok paliw konwencjonalnych, z powodzeniem obserwujemy próby wykorzystania odnawialnych źródeł energii. Energia odnawialna to energia, której zasoby odtwarzają się w sposób naturalny, bez ingerencji człowieka, której wykorzystanie nie powoduje zmiany stanu źródła tej energii ani zakłócenia środowiska naturalnego (Gronowicz 2008). Aby energię tę wykorzystać, należy ją przekształcić. Można tego dokonać wykorzystując pompę ciepła, czyli urządzenie odzyskujące ciepło z otoczenia i przekazujące do odbiornika (Langley 2001). Dzięki pompie ciepła możliwe jest przetwarzanie niskotemperaturowego ciepła na wyższy poziom energetyczny. Umożliwia to efektywne wykorzystanie ciepła w celu ogrzewania pomieszczeń, przygotowania ciepłej wody użytkowej, ogrzewania wody w basenach oraz wentylacji i klimatyzacji (Kampa 2008). Pompy ciepła pracują na odwrotnej zasadzie niż tradycyjne systemy ogrzewania. Korzystają z zasobów energii zakumulowanej przez otaczające środowisko, posiadającej temperaturę niższą, niż wymagana jest do ogrzewania budynków czy wody użytkowej i podwyższają ją do niezbędnego poziomu (Rubik 2011).

Stąd też potrzeba badań, w ramach których poznajemy możliwości zastosowania pomp ciepła w systemie ogrzewania budynku mieszkalnego, przygoto- 
wanego pod wynajem zarówno w lecie, jak i w zimie. W warunkach polskich do współpracy $\mathrm{z}$ pompami ciepła najbardziej nadają się systemy centralnego ogrzewania typu wodnego. Wynika to $\mathrm{z}$ faktu, że $\mathrm{CO}$ wodne jest najbardziej rozpowszechnionym systemem centralnego ogrzewania. Pompa ciepła w tym systemie może pracować zarówno jako jedyne źródło ciepła, jak i równoległe bądź alternatywne (Niezgoda 1996; Szargut 1997).

\section{Cel i metoda badawcza}

Celem analizy było ustalenie parametrów pracy solankowej pompy ciepła (SPC) wytwarzającej energię cieplną na potrzeby ogrzewania oraz przygotowania cieplej wody użytkowej (CWU) w budynku mieszkalnym, przeznaczonym pod wynajem, położonym na południu Polski w III strefie klimatycznej w Euroregionie Beskidy. Przyjęto wykorzystanie dolnego źródła ciepła w postaci poziomych kolektorów gruntowych $\mathrm{w}$ usytuowanych $\mathrm{w}$ gruntach gliniastych wilgotnych lub piaszczystych suchych. W poszczególnych wariantach pracy pompy, górne źródło ciepła stanowi wodna instalacja grzewcza o parametrach: temperatura wody zasilającej grzejniki $55^{\circ} \mathrm{C}$, temperatura wody powrotnej $45^{\circ} \mathrm{C}$ lub odpowiednio $45^{\circ} \mathrm{C} / 35^{\circ} \mathrm{C}$. Przyjęto monowalentny system pracy pompy ciepła.

Analizę przeprowadzono przy wykorzystaniu komputerowego programu symulacyjnego Vito-WP firmy Viessmann (www.wiessmann.pl). Po wprowadzeniu danych dotyczących lokalizacji oraz sezonowego zapotrzebowania na ciepło, dla założonych parametrów gruntu oraz temperatur instalacji grzewczej program obliczył niezbędną powierzchnię działki, na której zlokalizowana będzie wężownica absorbera. Dodatkowo określił jej długość, średnicę oraz wielkość przepływu solanki. Dla przyjętych powierzchni absorbera program wyznaczył czas pracy pomp w poszczególnych wariantach oraz ilość uzyskiwanej energii cieplnej, a także współczynnik efektywności pompy (COP).

\section{Charakterystyka budynku mieszkalnego}

Analizowany budynek położony jest na południu Polski w III strefie klimatycznej w Euroregionie Beskidy w miejscowości Jawor. Jawor jest obecnie prężnym ośrodkiem z rozwijającym się sektorem handlu i usług. W okolicy znajduje się florystyczny rezerwat przyrody Wąwóz Myśliborski i zbiornik retencyjny Słup. Najbliższa stacja meteorologiczna zlokalizowana w Bielsku-Białej odda- 
lona jest o ok. 20 kilometrów. Budynek jednorodzinny wolnostojący posadowiony jest na działce o powierzchni $714 \mathrm{~m}^{2}$. Budynek został wybudowany w latach 70. XX wieku, posiada powierzchnię użytkową $88,21 \mathrm{~m}^{2}$. Poddany został modernizacji w 2000 roku. Kondygnacja mieszkalna składa się z 3 pokoi, kuchni, przedpokoju, łazienki oraz spiżarni. Na kondygnacji parteru ściany zewnętrzne wykonano jako warstwowe z gazobetonu gr. $24 \mathrm{~cm}$ oraz cegły pełnej gr. $12 \mathrm{~cm}$ ocieplone styropianem gr. $8 \mathrm{~cm}$. Budynek przez cały rok jest wynajmowany. Centralne ogrzewanie wodne zostało zmodernizowane na początku 2000 roku. Istniejące stare żeliwne grzejniki zastąpiono stalowymi grzejnikami płytowymi typu Compact 11 i 22 firmy Purmo (www.purmo.com) Ciepła woda jest przygotowywana w sezonie grzewczym w zasobniku o pojemności 100 litrów współpracującym z instalacja $\mathrm{CO}$.

\section{Charakterystyka energetyczna budynku}

Obliczenia sezonowego zapotrzebowania na ciepło wykonano zgodnie z metodyką zawartą w normach (PN-EN 1254: 2003, PN-EN 13790: 2009) oraz rozporządzeniu (Rozporządzenie...). Przeprowadzona charakterystyka energetyczna pozwoliła na określenie zapotrzebowania na energię użytkową, końcową i pierwotną w analizowanym budynku. Zebrane dane przedstawiono w tabeli 1 .

Tabela 1

Zapotrzebowanie na energię użytkową i końcową

\begin{tabular}{|c|c|c|c|}
\hline Rodzaj energii & Zasilana instalacja & $\begin{array}{c}\text { Zapotrzebowanie } \\
\text { sezonowe } \\
(\mathrm{kWh} / \text { rok })\end{array}$ & $\begin{array}{c}\text { Zapotrzebowanie sezonowe } \\
\text { w odniesieniu do } \\
\text { powierzchni }\left(\mathrm{kWh} / \mathrm{rok} / \mathrm{m}^{2}\right)\end{array}$ \\
\hline \multirow{3}{*}{ Energia użytkowa } & do ogrzewania $\mathrm{Q}_{\mathrm{H}, \mathrm{nd}}$ & 10730,21 & 121,64 \\
\hline & do podgrzania CWU $\mathrm{Q}_{\mathrm{W}, \text { nd }}$ & 602,18 & 6,83 \\
\hline & $\begin{array}{c}\text { Suma energii } \\
\mathrm{Q}_{\mathrm{H}, \mathrm{nd}}+\mathrm{Q}_{\mathrm{W}, \mathrm{nd}} \\
\end{array}$ & 11332,39 & 128,47 \\
\hline \multirow{3}{*}{ Energia końcowa } & do ogrzewania $\mathrm{Q}_{\mathrm{KH}}$ & 12056,42 & 136,68 \\
\hline & do podgrzania CWU $\mathrm{Q}_{\mathrm{KW}}$ & 1003,63 & 11,38 \\
\hline & Suma energii $\mathrm{Q}_{\mathrm{K}}$ & 13060,05 & 148,06 \\
\hline \multirow{3}{*}{ Energia pierwotna } & do ogrzewania $\mathrm{Q}_{\mathrm{PH}}$ & 13836,41 & 156,86 \\
\hline & do podgrzania $\mathrm{CWU} \mathrm{Q}_{\mathrm{PW}}$ & 1103,99 & 12,52 \\
\hline & Suma energii $\mathrm{Q}_{\mathrm{P}}$ & 14940,40 & 169,37 \\
\hline
\end{tabular}

Źródło: opracowanie własne. 


\section{Analiza wykorzystania pomp ciepła w budynku}

Do obliczenia i optymalizacji instalacji z gruntowym wymiennikiem ciepła wykorzystano program symulacyjny firmy Viessmann (www.wiessmann.pl). Porównano następujące warianty pracy pompy ciepła:

- grunt glina wilgotna, temperatura źródła górnego (grzejniki) 55/45,

- grunt glina wilgotna, temperatura źródła górnego (grzejniki) 45/35,

- grunt piasek suchy, temperatura źródła górnego (grzejniki) 55/45,

- grunt piasek suchy, temperatura źródła górnego (grzejniki) 45/35.

Po wprowadzeniu danych badanego budynku do programu, uzyskano miesięczne zapotrzebowanie na ciepło (rys. 1).

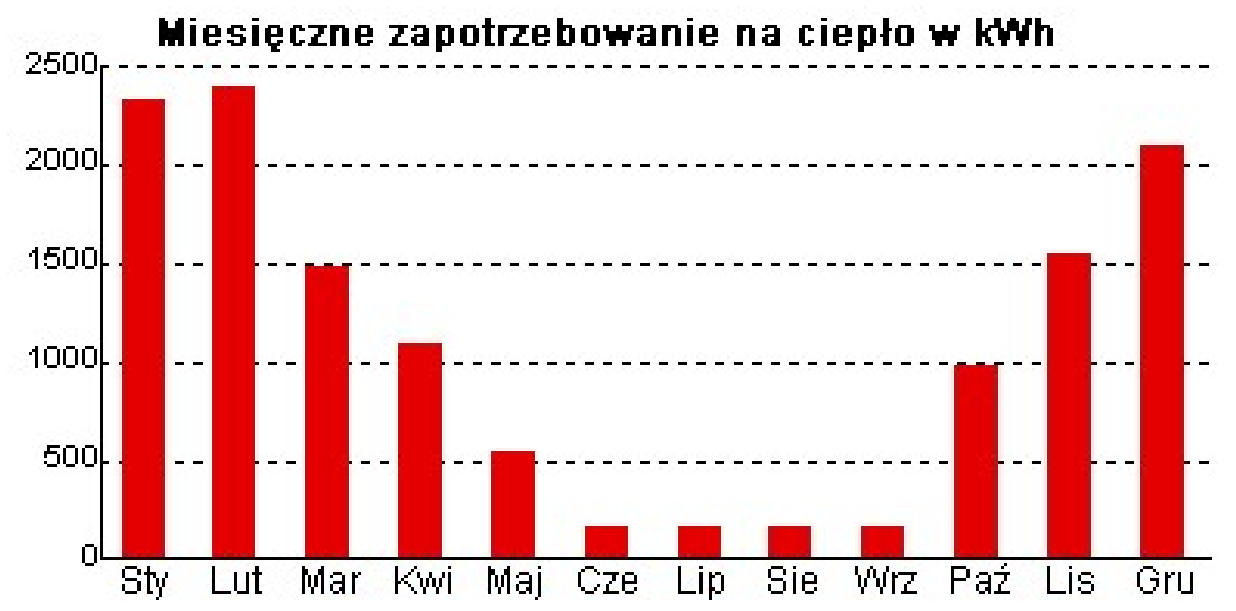

przez pompę ciepła

Rysunek 1. Miesięczne zapotrzebowanie na ciepło

Źródło: opracowanie własne.

Zapotrzebowanie dla wszystkich rozpatrywanych wariantów jest jednakowe, gdyż wynika ono z lokalizacji budynku i jego energochłonności, a nie z zastosowanej pompy ciepła. Najwyższe zapotrzebowanie na ciepło obserwujemy w okresie zimowym, kiedy występują najniższe temperatury zewnętrzne. W okresie od czerwca do września zapotrzebowanie na ciepło wynika wyłącznie z przygotowania ciepłej wody użytkowej. 
Obliczony czas pracy pomp dla analizowanych wariantów gruntowo-wodnych przedstawiono w tabeli 2. Czas ten jest zróżnicowany. Najdłużej pracować będzie pompa w gruncie gliniastym wilgotnym przy temperaturze górnego źródła ciepła na poziomie $45^{\circ} \mathrm{C} / 35^{\circ} \mathrm{C}$, najkrócej natomiast $\mathrm{w}$ gruncie piaszczystym suchym na poziomie $45^{\circ} \mathrm{C} / 35^{\circ} \mathrm{C}$. Związane jest to z rodzajem gruntu. Absorber w gruncie gliniastym pobiera wyższe jednostkowe ilości ciepła, jednakże w czasie trwania sezonu grzewczego na skutek wyziębienia źródła dolnego następuje w kolektorze spadek temperatury solanki i gruntu w otoczeniu kolektora większy niż ma to miejsce w przypadku kolektora poziomego w gruncie piaszczystym. Grunty gliniaste charakteryzują się niższym współczynnikiem filtracji w stosunku do gruntów piaszczystych, co powoduje wolniejszą migrację ciepła i wilgoci w tych gruntach.

Tabela 2

Czas pracy pomp

\begin{tabular}{|c|c|c|c|}
\hline $\begin{array}{c}\text { Rodzaj gruntu i temperatura } \\
\text { źródła górnego }\end{array}$ & $\begin{array}{c}\text { Do ogrzewania budynku } \\
(\mathrm{h} / \mathrm{rok})\end{array}$ & $\begin{array}{c}\text { Do przygotowania CWU } \\
(\mathrm{h} / \mathrm{rok})\end{array}$ & $\begin{array}{c}\text { Suma } \\
(\mathrm{h} / \mathrm{rok})\end{array}$ \\
\hline $\begin{array}{c}\text { Grunt glina }- \text { źródło górne } \\
55^{\circ} \mathrm{C} / 45^{\circ} \mathrm{C}\end{array}$ & 1177 & 200 & 1377 \\
\hline $\begin{array}{c}\text { Grunt glina }- \text { źródło górne } \\
45^{\circ} \mathrm{C} / 35^{\circ} \mathrm{C}\end{array}$ & 1487 & 258 & 1745 \\
\hline $\begin{array}{c}\text { Grunt piasek }- \text { źródło górne } \\
55^{\circ} \mathrm{C} / 45^{\circ} \mathrm{C}\end{array}$ & 1110 & 190 & 1300 \\
\hline $\begin{array}{c}\text { Grunt piasek }- \text { źródło górne } \\
45^{\circ} \mathrm{C} / 35^{\circ} \mathrm{C}\end{array}$ & 1406 & 245 & 1651 \\
\hline
\end{tabular}

Źródło: opracowanie własne.

W tabeli 3 zestawiono wielkość pobranego ciepła z dolnego źródła. Wielkości pobranego ciepła z płaskiego kolektora poziomego będą wyższe dla parametrów pracy instalacji $45^{\circ} \mathrm{C} / 35^{\circ} \mathrm{C}$ dla gruntu gliniastego i piaszczystego.

Tabela 3

Wielkość pobranego ciepła z kolektora gruntowego

\begin{tabular}{|c|c|c|c|}
\hline $\begin{array}{c}\text { Rodzaj gruntu i temperatura } \\
\text { źródła górnego }\end{array}$ & $\begin{array}{c}\text { Do ogrzewania budynku } \\
(\mathrm{kWh} / \mathrm{rok})\end{array}$ & $\begin{array}{c}\text { Do przygotowania CW } \\
(\mathrm{kWh} / \mathrm{rok})\end{array}$ & $\begin{array}{c}\text { Suma } \\
(\mathrm{kWh} / \mathrm{rok})\end{array}$ \\
\hline $\begin{array}{c}\text { Grunt glina }- \text { źródło górne } \\
55^{\circ} \mathrm{C} / 45^{\circ} \mathrm{C}\end{array}$ & 8476 & 1344 & 9820 \\
\hline $\begin{array}{c}\text { Grunt glina }- \text { źródło górne } \\
45^{\circ} \mathrm{C} / 35^{\circ} \mathrm{C}\end{array}$ & 8778 & 1318 & 10196 \\
\hline $\begin{array}{c}\text { Grunt piasek }- \text { źródło górne } \\
55^{\circ} \mathrm{C} / 45^{\circ} \mathrm{C}\end{array}$ & 8645 & 1375 & 10020 \\
\hline $\begin{array}{c}\text { Grunt piasek }- \text { źródło górne } \\
45^{\circ} \mathrm{C} / 35^{\circ} \mathrm{C}\end{array}$ & 8923 & 1351 & 10274 \\
\hline
\end{tabular}

Źródło: opracowanie własne. 


\section{Roczna wartość współczynnika efektywności (COP)}

Porównując roczne wartości współczynnika efektywności (bez energii pomocniczej) najlepsze parametry na poziomie 4,4 uzyskano dla gruntu piaszczystego i parametrów pracy grzejników na poziomie $45^{\circ} \mathrm{C} / 35^{\circ} \mathrm{C}$. Najniższą wartość współczynnika na poziomie 3,9 odnotowano dla absorbera usytuowanego w gruncie z gliny i parametrach pracy górnego źródła $55^{\circ} \mathrm{C} / 45^{\circ} \mathrm{C}$. Dane dotyczące dolnego źródła przedstawiono w tabeli 4.

Tabela 4

Wybrane wyniki obliczeń SPC dla analizowanych wariantów

\begin{tabular}{|c|c|c|c|c|c|}
\hline Rodzaj gruntu & $\begin{array}{c}\text { Powierzchnia } \\
\text { absorbera }\left(\mathrm{m}^{2}\right)\end{array}$ & $\begin{array}{c}\text { Długość } \\
\text { absorbera }(\mathrm{m})\end{array}$ & $\begin{array}{c}\text { Liczba } \\
\text { obiegów }\end{array}$ & $\begin{array}{c}\text { Strumień } \\
\text { przepływu } \\
\left(\mathrm{m}^{3} / \mathrm{h}\right)\end{array}$ & $\begin{array}{c}\text { Współczynnik efek- } \\
\text { tywności COP }\end{array}$ \\
\hline Glina wilg. 55/45 & 235 & 240 & 2 & 2,3 & 3,9 \\
\hline Glina wilg. 45/35 & 216 & 220 & 2 & 1,8 & 4,2 \\
\hline $\begin{array}{c}\text { Piasek suchy } \\
55 / 45\end{array}$ & 587 & 599 & 4 & 2,3 & 4,1 \\
\hline $\begin{array}{c}\text { Piasek suchy } \\
45 / 35\end{array}$ & 518 & 528 & 4 & 1,8 & 4,4 \\
\hline
\end{tabular}

Źródło: opracowanie własne.

Z uzyskanych danych wynika, że niezbędna powierzchnia działki pod kolektor płaski gruntowy waha się w przypadku wartości skrajnych od $587 \mathrm{~m}^{2}$ dla gruntu piaszczystego (55/45) do $216 \mathrm{~m}^{2}$ dla gruntu gliniastego (45/35). Dla kolektora $\mathrm{w}$ gruncie piaszczystym przy pracy górnego źródła z wartością 55/45 wielkość działki, na której usytuowany jest budynek, okazała się niewystarczająca. Działka ma powierzchnię $714 \mathrm{~m}^{2}$, ale poziomego absorbera gruntowego nie można sytuować pod budynkiem zajmującym $121 \mathrm{~m}^{2}$ oraz powierzchniami utwardzonymi działki zajmującymi $35 \mathrm{~m}^{2}$. Liczba obiegów (pętli) w absorberze wyniosła 2 dla rozpatrywanych wariantów dla gruntu gliniastego oraz $4 \mathrm{w}$ przypadku wariantów z gruntem piaszczystym. Dla wszystkich wariantów dobrano poziomy wymiennik ciepła $\mathrm{w}$ postaci wężownicy wykonanej z rury polietylenowej o średnicy zewnętrznej $40 \mathrm{~mm}$ i grubości ścianki 3,7 mm. Długość poziomego wymiennika zlokalizowanego $\mathrm{w}$ gruncie piaszczystym, przy parametrach źródła górnego $55^{\circ} \mathrm{C} / 45^{\circ} \mathrm{C}$ okazała się najdłuższa i wyniosła $599 \mathrm{~m}$. Do kalkulacji program $\mathrm{z}$ bazy danych przyjmuje zróżnicowane jednostkowe ilości pobieranego ciepła z $1 \mathrm{~m}$ wymiennika w zależności od rodzaju gruntu, jego uwilgotnienia i głębokości usytuowania rurociągu. 


\section{Podsumowanie i wnioski}

Ograniczeniem w stosowaniu pomp ciepła w budownictwie mieszkaniowym jednorodzinnym nie jest brak technologii czy dostępności pomp ciepła, które występują na rynku o mocach dostępnych praktycznie do każdego typu budynku jednorodzinnego. Barierą w wykorzystaniu gruntowych pomp ciepła z płaskimi kolektorami poziomymi może okazać się natomiast zbyt mała powierzchnia działki niezbędna do ułożenia kolektora o żądanej mocy. Należy także wskazać na ograniczenie spowodowane źródłem ciepła na poziomie górnym. Dotyczy to zwłaszcza istniejących budynków jednorodzinnych niepoddanych termomodernizacji, gdzie występuje centralne ogrzewanie wodne typu grzejnikowego. Spadek parametrów grzewczych źródła górnego do wartości $55^{\circ} \mathrm{C} / 45^{\circ} \mathrm{C}$ lub $45^{\circ} \mathrm{C} / 35^{\circ} \mathrm{C}$ niezbędnych do efektywnej pracy pomp ciepła może powodować konieczność głębokiej ingerencji w istniejący system grzewczy. W niektórych sytuacjach może to doprowadzić do konieczności całkowitej wymiany instalacji centralnego ogrzewania a nie tylko poszczególnych grzejników.

Przeprowadzone badania pozwoliły na wyciągnięcie wniosków:

1. Miesięczne zapotrzebowanie analizowanego budynku na ciepło będzie najwyższe w miesiącach grudzień-luty, kiedy to wyniesie 2000-2500 kWh. Wynika to $\mathrm{z}$ faktu, że w tym okresie występują najniższe temperatury zewnętrzne, a ciepło potrzebne jest zarówno do ogrzewania, jak i przygotowania CWU.

2. Powierzchnia poziomego gruntowego wymiennika ciepła przy gruntach gliniastych wilgotnych jest prawie 2,5-krotnie mniejsza w porównaniu do gruntów piaszczystych suchych.

3. Dla dobranych powierzchni wymiennika gruntowego czas pracy SPC jest najdłuższy w przypadku wykorzystania gliny wilgotnej i parametrów górnego źró$\mathrm{dła} 45^{\circ} \mathrm{C} / 35^{\circ} \mathrm{C}$ i wynosi $1745 \mathrm{~h} /$ rok. Czas pracy SPC jest najkrótszy dla wariantu; piasek suchy i parametru górnego źródła $55^{\circ} \mathrm{C} / 45^{\circ} \mathrm{C}$ i wynosi $1300 \mathrm{~h} /$ rok .

4. Dla analizowanych przypadków najkorzystniejszy współczynnik efektywności uzyskano w wariancie; piasek suchy, temperatura 45/35. Współczynnik ten wynosi 4,4 .

5. Współczynnik efektywności pompy ciepła jest wyższy przy współpracy z niskotemperaturowymi górnymi źródłami ciepła.

6. Dla płaskiego kolektora gruntowego pracującego $\mathrm{w}$ gruncie piaszczystym i parametrach górnego źródła na poziomie $55^{\circ} \mathrm{C} / 45^{\circ} \mathrm{C}$ powierzchnia działki okazała się niewystarczająca. 


\section{Bibliografia}

Gronowicz J., Niekonwencjonalne źródta energii pomp ciepła. Dobór gruntowych wymienników ciepła. „, Technika chtodnicza i klimatyzacyjna”, 2008 nr 4 (95),.

Kampa M., Castanas E., Human health effects of air pollution, „Environmental Pollution, 2008, Vol. 151, Issue 2.

Langley B.C., Heat Pump Technology, Prentice Hall 2001.

Niezgoda B., Ekonomiczność stosowania pomp ciepta do ogrzewania budynków mieszkalnych w warunkach polskich. „Technika Chłodnicza i Klimatyzacyjna”, 1996, nr 6.

Rubik M., Pompy ciepła w systemach geotermii niskotemperaturowej, Multico Oficyna Wydawnicza 2011.

Szargut J., Pompy ciepła w systemach grzewczych, Materiały Seminarium Komitetu Problemów Energetyki PAN, Kraków/Zakopane, maj 1997.

Zaręba D., Ekoturystyka, Wydawnictwo Naukowe PWN 2010.

PN-EN 12524: 2003, Materiały i wyroby budowlane - Właściwości cieplno-wilgotnościowe - Tabelaryczne wartości obliczeniowe.

PN-EN 13790: 2009, Energetyczne właściwości użytkowe budynków. Obliczanie zużycia energii na potrzeby ogrzewania i chłodzenia.

Rozporządzenie Ministra Infrastruktury z dnia 6.11.2008 r. w sprawie metodologii obliczania charakterystyki energetycznej budynku i lokalu mieszkalnego lub części budynku stanowiącego samodzielną całość techniczno-użytkową oraz sposobu sporządzania i wzorów świadectw ich charakterystyki energetycznej (Dz.U. nr 201, poz. 1240).

www.purmo.com/ Katalog techniczny grzejniki płytowe.

www.viessmann.pl/pl/strefa_projektanta/oprogramowanie/vito-wp.html.

\section{Analysis of the possibilities of using heat pumps for residential building located in the Beskids Euroregion}

\section{Summary}

For a rent-intended demonstration dwelling house, placed in the Beskids Euroregion, heat pumps were chosen and the absorber area was calculated for the given object with the use of a computer program Vito-WP Viessmann. Basing on the performed energetic characteristics of the building, the work of a brine heat pump in a monovalent system was analyzed. A lower heat source was assumed in the form of horizontal ground collectors placed in humid clay as well as in dry sand subsoil. There was presented the influence of feeding of the upper heat source with the parameters $55^{\circ} \mathrm{C} / 45^{\circ} \mathrm{C}$ and $45^{\circ} \mathrm{C} / 35^{\circ} \mathrm{C}$ on the work parameters of heat pump. 